\title{
Editorial
}

\section{Enfermagem - transformações e formação profissional}

\author{
Soraia Dornelles Schoeller*
}

Vivemos numa época de transformaçóes sociais cada vez mais intensas e profundas. Nunca foi tão fácil conhecer tantas realidades ao mesmo tempo. Nunca as informações chegaram com tamanha velocidade a inúmeras pessoas simultaneamente. Hoje a realidade palpável e imediata se confunde com a realidade virtual. Os mecanismos de conhecimento, com o advento da internet e sua socialização, se multiplicaram infinitamente e nos colocam em contato constante com novos e diferentes conhecimentos, em todas as disciplinas. Vemos o surgimento de novas áreas de conhecimento em praticamente todos os campos e profissóes. Aproximando este raciocínio à enfermagem devemos refletir sobre as consequências disso para a nossa profissão: Quais são? Estamos conseguindo acompanhar estas mudanças? Pensemos na nossa formação e em uma das finalidades de nosso trabalho: o cuidado. A enfermagem tem na sua essência o cuidado terapêutico, a partir do conhecimento profundo do sujeito enfermo, nas dimensóes biológica, espiritual, afetiva, econômica, social e cultural [1]. Isso resulta que o conhecimento do outro na sua integralidade é condição para a realização deste cuidado, ou, visto de outro modo: o cuidado de enfermagem não se realiza sem o conhecimento do outro, a partir da ótica do outro e do significado que esta outra pessoa atribui a sua vida em geral e ao problema que está enfrentando em particular. A formação profissional, portanto, deve fornecer ferramentas para que isso aconteça.

Segundo as diretrizes governamentais brasileiras vigentes para o profissional de enfermagem [2], o enfermeiro deve ser generalista, humanista, crítico e reflexivo. Para isso, uma de suas competências é "atuar profissionalmente, compreendendo a natureza humana em suas dimensóes, em suas expressóes e fases evolutivas" [2:2], identificando as necessidades do(s) sujeito(s) cuidado(s).

Mais recentemente, o Conselho Federal de Enfermagem, através da Resolução 383/2011 [2] fixou em 44 as especialidades de enfermagem, acrescendo àquelas já existentes: citando algumas, temos hoje desde enfermagem materno infantil à aeroespacial, perpassando pela Auditoria e Pesquisa, Cardiologia (Perfusionista e Hemodinâmica), Centro Cirúrgico (Central de Material e Esterilização e Recuperação pós-anestésica), dermatologia (Estomaterapia, Feridas e Ostomias), Diagnóstico por Imagens, Endocrinologia, Farmacologia, Gerenciamento/Gestão, Hematologia e Hemoterapia, Informática em Saúde, Legislação, Ética e Bioética, Nutrição Parenteral e Enteral, Oftal- 
mologia, Otorrinolaringologia, Políticas Publicas, Saúde Complementar, Saúde Indígena, Sexologia Humana, Terapias Holísticas Complementares, Traumato-Ortopedia, e, offshore e aquaviária.

A questão que coloco aqui para a reflexão é: a formação profissional acompanha estas transformaçóes? Se, e a história da enfermagem reflete as transformações sociais, como a formação profissional as está acompanhando? As grades curriculares conseguem disponibilizar disciplinas de modo a que o egresso seja de fato generalista e humanista e conheçam quais são as possibilidades que o enfermeiro tem no atual mercado de trabalho? As Escolas de Enfermagem proporcionam ao acadêmico experiências compatíveis com as atuais realidades? Há trocas de experiências entre as escolas para socializar as açóes realizadas para a formação profissional?

Esta é uma reflexão urgente e necessária, para que caminhemos cada vez mais na construção de profissionais éticos, humanos e reconhecidos.

\section{Referências}

1. Schoeller SD, Leopardi MT, Ramos FR. Cuidado: eixo da vida, desafio da enfermagem. Rev Enferm UFSM 2011;1(1):88-96.

2. Brasil. Conselho Nacional de Educação. Resolução CNE/CES no 3, de 7 de novembro de 2001.

3. Brasil. Conselho Federal de Enfermagem. Resolução no 388, de 18 de outubro de 2011. 